\title{
Lipopolysaccharide-induced murine embryonic resorption involves nitric oxide-mediated inhibition of the NAD + -dependent 15-hydroxyprostaglandin dehydrogenase
}

\author{
Julieta Aisemberg, María V Bariani, Claudia A Vercelli, Manuel L Wolfson and Ana M Franchi \\ Centro de Estudios Farmacológicos y Botánicos (CEFYBO, CONICET-UBA), Facultad de Medicina, Universidad de \\ Buenos Aires, Buenos Aires, Argentina
}

Correspondence should be addressed to J Aisemberg, Paraguay 2155, Piso 16, C1121ABG, Buenos Aires, Argentina; Email: jaisemberg@yahoo.com.ar

\begin{abstract}
The initial inactivation of prostaglandins (PGs) is mediated by 15-hydroxyprostaglandin dehydrogenase (15-PGDH). PGs are potent mediators of several biological processes, including inflammation and reproduction. In uterus, PGs play a key role in infectioninduced pregnancy loss, in which concentration of this mediator increased. This process is accompanied with the induction of nitric oxide synthase expression and a marked increase in uterine levels of nitric oxide. There is no information concerning nitric oxide contribution to potential changes in PG catabolism, but experimental evidence suggests that nitric oxide modulates PG pathways. The specific objectives of the study were to evaluate the protein expression of HPGD (15-PGDH) and to characterize the nitric oxide-dependent regulation of this enzyme in a model of lipopolysaccharide (LPS)-induced embryonic resorption. Results show that LPS decreased HPGD protein expression and augmented PGE synthase activity; therefore, PGE $_{2}$ levels increased in uterus in this inflammatory condition. Just as LPS, the treatment with a nitric oxide donor diminished HPGD protein expression in uterine tissue. In contrast, the inhibition of nitric oxide synthesis both in control and in LPS-treated mice increased 15-PGDH levels. Also, we have found that this enzyme and $\mathrm{PGE}_{2}$ levels are not modulated by peroxynitrite, an oxidant agent derived from nitric oxide. This study suggests that LPS and nitric oxide promote a decrease in the ability of the uterus for PG catabolism during bacterially triggered pregnancy loss in mice.

Reproduction (2012) 144 447-454
\end{abstract}

\section{Introduction}

Microbial infections are known to cause miscarriage and preterm labor (Romero et al. 1988, Lamont \& Sawant 2005) but their mechanisms are still not fully elucidated. Lipopolysaccharide (LPS), a major cell wall component of gram-negative bacteria, induces activation of immune cells. Activated macrophages produce several inflammatory cytokines including tumor necrosis factor $\alpha$, interleukin 6 and 12, which, when in excess, leads to the onset of reproductive disorders or diseases (Penta et al. 2003). We have previously developed a mouse model to study the mechanisms of LPS-induced pregnancy loss. The administration of $1 \mu \mathrm{g} / \mathrm{g}$ of body weight (i.p.) of LPS in mice on day 7 of pregnancy produced complete embryonic resorption at $24 \mathrm{~h}$. We have observed that the decidua, which envelops the embryo, was necrotized $24 \mathrm{~h}$ after LPS injection and this resorbed tissue was expelled the following day. In this model, nitric oxide and prostaglandins (PGs) are highly produced in implantation sites of mouse uterus during the infection/ inflammation-induced embryonic resorption process (Ogando et al. 2003, Aisemberg et al. 2007).

PG biosynthesis is catalyzed by cyclooxygenase 1 and 2 enzymes (Rouzer \& Marnett 2009) and the first step of its inactivation is due to the NAD+-dependent 15-hydroxyprostaglandin dehydrogenase that catalyzes the conversion of primary PGs to their biologically inactive 15-keto derivatives (Tai et al. 2006). The products, 15-keto metabolites, exhibit greatly reduced biological activities rendering this enzyme being a key enzyme responsible for the biological inactivation of these eicosanoids. A tight control over PG metabolism is critical for the maintenance of pregnancy, in part because they act as potent uterotonins affecting myometrial contractility. During early gestation, HPGD (15-PGDH) activity has been shown to increase (Keirse et al. 1985), and for most of the duration of pregnancy, 15-PGDH minimizes myometrial contractility, keeping PGs synthesized by amnion or chorion (Sangha et al. 1994). Therefore, changes in HPGD protein levels or 


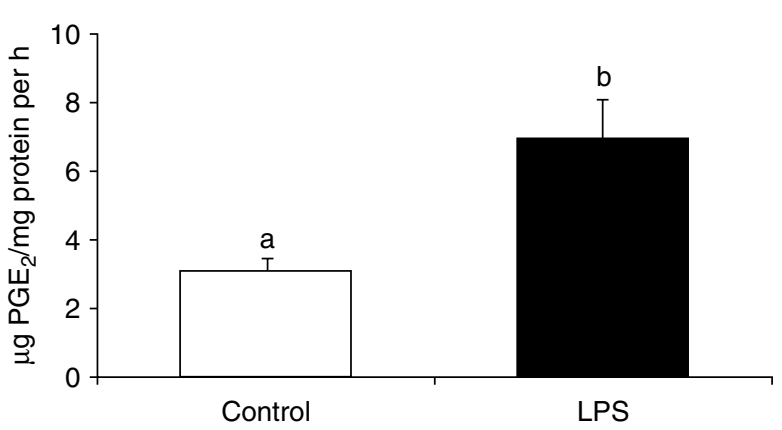

Figure 1 Effect of LPS treatment on prostaglandin E synthase activity. $\mathrm{BALB} / \mathrm{C}$ mice were injected on day 7 of gestation and they were killed after $6 \mathrm{~h}$ of LPS $(1 \mu \mathrm{g} / \mathrm{g})$ or vehicle (PBS) treatment. In uterus, enzyme activity was assessed by conversion of $\mathrm{PGH}_{2}$ to $\mathrm{PGE}_{2}$. $\mathrm{PGE}_{2}$ levels were determined by RIA. Results were expressed as $\mu \mathrm{g} \mathrm{PGE}_{2} / \mathrm{mg}$ protein per $h$. Values are mean \pm S.E.M., $n=5$ mice per group. Comparisons of means were made with Student's $t$-test. Dissimilar superscripts denote significantly different values $(P<0.05)$.

activity play important roles in regulating the catabolism and availability of primary PGs that are implicated in physiological and pathological processes. Despite the physiological importance of $15-\mathrm{PGDH}$, little is understood about the mechanisms involved in regulating its expression. Expression and activity of 15-PGDH have been demonstrated in reproductive tissues of different species (Casey et al. 1980, Kankofer 1999, Gao et al. 2007). LPS treatment decreases activity of 15-PGDH in mouse and human fetal membranes at term (Brown et al. 1998, Wang \& Hirsch 2003) and alters Hpgd mRNA and protein levels in mouse and rat lung during sepsis (Hahn et al. 1998, Ivanov \& Romanovsky 2004).

As we mentioned earlier, in response to LPS treatment, implantation sites produce various bioactive molecules, including nitric oxide, PGs, reactive oxygen species, and pro-inflammatory cytokines. So the cellular toxic effects of inducible nitric oxide synthase derivative products contribute to the detrimental effects of the endotoxin on tissue functions. The peroxynitrite anion is a short-lived oxidant and nitrating molecule that is produced by the reaction of nitric oxide and superoxide radicals. Tyrosine nitration is becoming increasingly recognized as a functionally posttranslational modification that serves as an indicator of nitric oxide-mediated oxidative inflammatory reactions. We have previously found that after LPS administration, uterine cyclooxygenase enzyme was nitrated in tyrosine residues. Moreover, we found that cyclooxygenase-nitrated levels were higher than nonmodified cyclooxygenase expression (Aisemberg et al. 2007).

The increment in PG output induced by LPS could be caused by increased synthesis as well as by diminished PG degradation. The objectives of this work were to evaluate the participation of PG catabolism in modulating prostanoid levels in uterus as part of the mechanism by which LPS-induces embryonic resorption, and the possible regulation of $15-\mathrm{PGDH}$ by nitric oxide and nitric oxide-derived reactive species.

\section{Results}

\section{Effect of LPS on PGE synthase activity}

We have previously found that injection of LPS causes total embryonic resorption after $24 \mathrm{~h}$ of treatment (Ogando et al. 2003). At the maternal-fetal interface, we have shown that there is an increase in $\mathrm{PGE}_{2}$ levels due to regulation of cyclooxygenase 2, a key enzyme in eicosanoid biosynthesis (Aisemberg et al. 2007). Cyclooxygenase enzymes catalyze the conversion of arachidonic acid to $P G$ endoperoxides $\left(\mathrm{PGG}_{2}\right.$ and subsequently to $\mathrm{PGH}_{2}$ ), which acts as a substrate for multiple isomerases that are individually responsible for the generation of eicosanoid products, including $\mathrm{PGE}_{2}$. PGE synthase isomerizes specifically to $\mathrm{PGE}_{2}$. Our first objective was to evaluate whether treatment with LPS could alter $\mathrm{PGE}_{2}$ production through the regulation of its specific synthase. The enzymatic activity through the conversion of $\mathrm{PGH}_{2}$ to $\mathrm{PGE}_{2}$ in uterine tissues was assessed. We observed that 6 -h treatment with endotoxin significantly increases PGE synthase activity, consistent with high levels of $\mathrm{PGE}_{2}$ observed (Fig. 1).

\section{Effect of LPS on HPGD protein expression}

There are several evidences about modulation of the PG pathways by LPS. Our main objective was to evaluate whether some type of regulation was possible in our model of early pregnancy loss, at level of PG catabolism. First, we evaluated whether treatment with endotoxin had an effect on HPGD protein expression of the uterus and decidua. Animals were injected with LPS $(1 \mu \mathrm{g} / \mathrm{g})$ on day 7 of gestation and were killed $6 \mathrm{~h}$ after treatment. Within the context of an infection, we identified the uterine expression of HPGD protein. On the contrary, this protein was barely detectable in decidua, both in control and in LPS-treated animals. As shown in Fig. 2, 15-PGDH expression is down-modulated in uterus under inflammatory conditions (at the time analyzed).

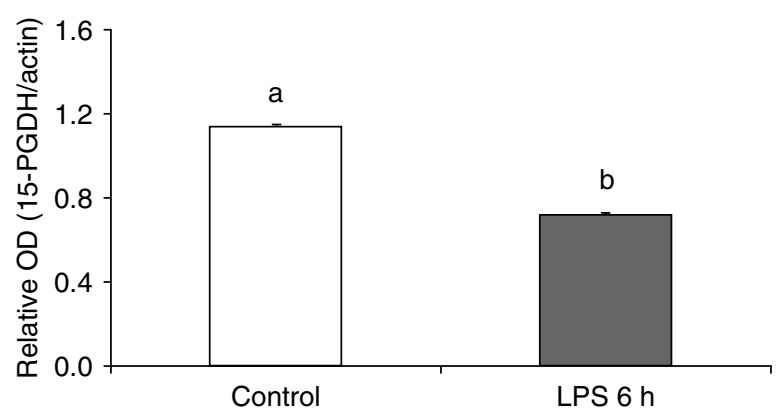

Figure 2 Effect of LPS treatment on HPGD protein expression. BALB/c mice were injected on day 7 of pregnancy with vehicle (PBS) or LPS $(1 \mu \mathrm{g} / \mathrm{g})$ and killed after $6 \mathrm{~h}$ of treatment. HPGD protein expression was determined in uterine tissue by western blot. Normalized data (OD 15-PGDH/OD actin) are expressed as mean \pm S.E.M., $n=5$ mice per group. Comparisons of means were made with Student's $t$-test. Dissimilar superscripts denote significantly different values $(P<0.001)$. OD, optical density. 


\section{Effect of LPS on PGE 2 catabolism}

PG levels in vivo depend on the balance between the relative activities of synthesis and degradation, and metabolic enzymes play crucial roles in this process. In addition to modulation of protein levels of HPGD by LPS, we studied whether LPS was able to modify the production of inactive metabolites of $\mathrm{PGE}_{2}$. Mice were treated for $6 \mathrm{~h}$ with LPS ( $1 \mu \mathrm{g} / \mathrm{g})$ on day 7 of gestation and implantation sites (uterus and decidua) were obtained. Metabolite quantification was assessed by ELISA (as described in the Materials and Methods section) and $\mathrm{PGE}_{2}$ levels were determined in the same sample by RIA. LPS administration to pregnant mice resulted in a significant increased $\mathrm{PGE}_{2}$ levels both in uterus and in decidua (Fig. 3A and $B$ respectively). A reduction of PGE metabolite levels was found only in uterine tissue after $6 \mathrm{~h}$ of treatment (Fig. 3A). These results suggest that under inflammatory conditions, LPS can regulate the levels of $\mathrm{PGE}_{2}$ in uterus not only by increasing its synthesis but also by decreasing its catabolism.

\section{Effect of nitric oxide and peroxynitrite on $\mathrm{PGE}_{2}$ catabolism}

It was reported that PGs may interact with nitric oxide biosynthetic pathway and vice versa. As mentioned repeatedly in this paper, there is an increase in the levels of PG and nitric oxide at implantation sites as a consequence of LPS injection. So there could be an interaction between these two pathways in our model of early pregnancy loss induced by infection.

We evaluated the effect of nitric oxide synthesis inhibition on HPGD protein expression. We treated mice with aminoguanidine, a selective inducible nitric oxide synthase inhibitor. As shown in Fig. 4A, this treatment increased 15-PGDH expression in control pregnant mice. In animals treated with LPS and aminoguanidine, we observed an increment on HPGD protein, which restored the levels of expression reduced by LPS injection (Fig. 4B). These data indicate that the expression of this catabolic enzyme is negatively modulated by endogenous nitric oxide levels both in physiological and inflammatory conditions.

The latter result suggests that nitric oxide is an LPS effector that contributes to the modulation of the expression of 15-PGDH. Given this, we administered a nitric oxide donor, $S$-nitroso- $\mathrm{N}$-acetyl-penicillamine (SNAP), to evaluate the relevance of nitric oxide in modulating PG catabolism. We observed a significant reduction in HPGD protein levels after $6 \mathrm{~h}$ of SNAP treatment (Fig. 5).

Peroxynitrite, an oxidizing and nitrating agent, is produced by the reaction between nitric oxide and superoxide. It may react with other reactive species or free radicals or directly with proteins, lipids, and DNA causing oxidative stress (Szabó et al. 2007). Peroxynitrite
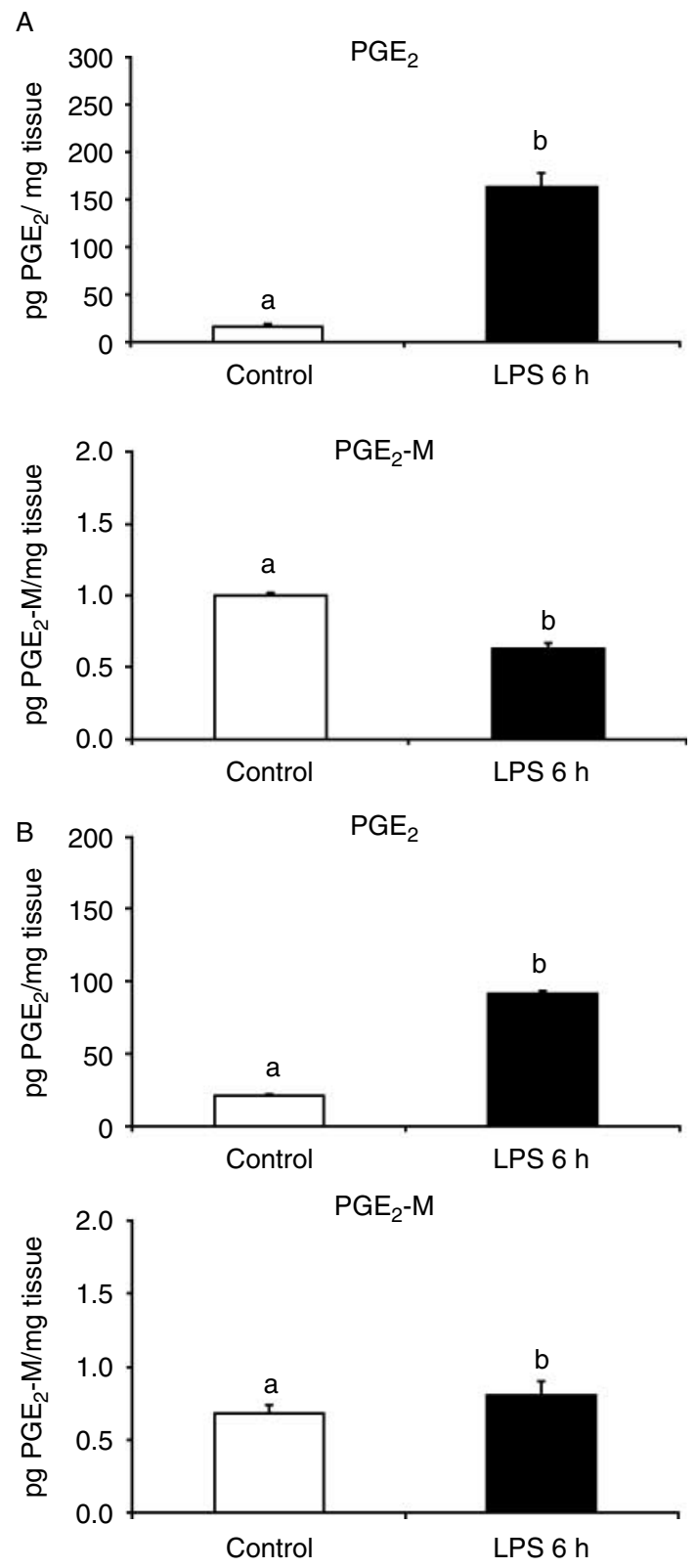

Figure 3 Effect of LPS treatment on $\mathrm{PGE}_{2}$ and PGE metabolites levels. $\mathrm{BALB} / \mathrm{C}$ mice were injected on day 7 of pregnancy with vehicle (PBS) or LPS $(1 \mu \mathrm{g} / \mathrm{g})$ and killed after $6 \mathrm{~h}$ of treatment. $\mathrm{PGE}_{2}$ and $\mathrm{PGE}_{2}$ metabolite $\left(\mathrm{PGE}_{2}-\mathrm{M}\right)$ levels were determined in uterus $(\mathrm{A})$ and decidua $(\mathrm{B})$ by RIA and EIA respectively. Results were expressed as pg $\mathrm{PGE}_{2}$ or $\mathrm{PGE}_{2}-\mathrm{M} / \mathrm{mg}$ tissue. Values are mean \pm s.E.M., $n=4$ per group. Comparisons of means were made with Student's $t$-test. Dissimilar superscripts denote significantly different values $(P<0.05)$.

is now being revealed as a key reactive species in pathological events associated with stimulation of tissue production of nitric oxide, as we previously observed in our model of pregnancy loss induced by LPS (Aisemberg et al. 2007). The formation of 3-nitrotyrosine in specific tyrosine residues can alter protein structure and function, implying that in certain pathological states, nitration is 

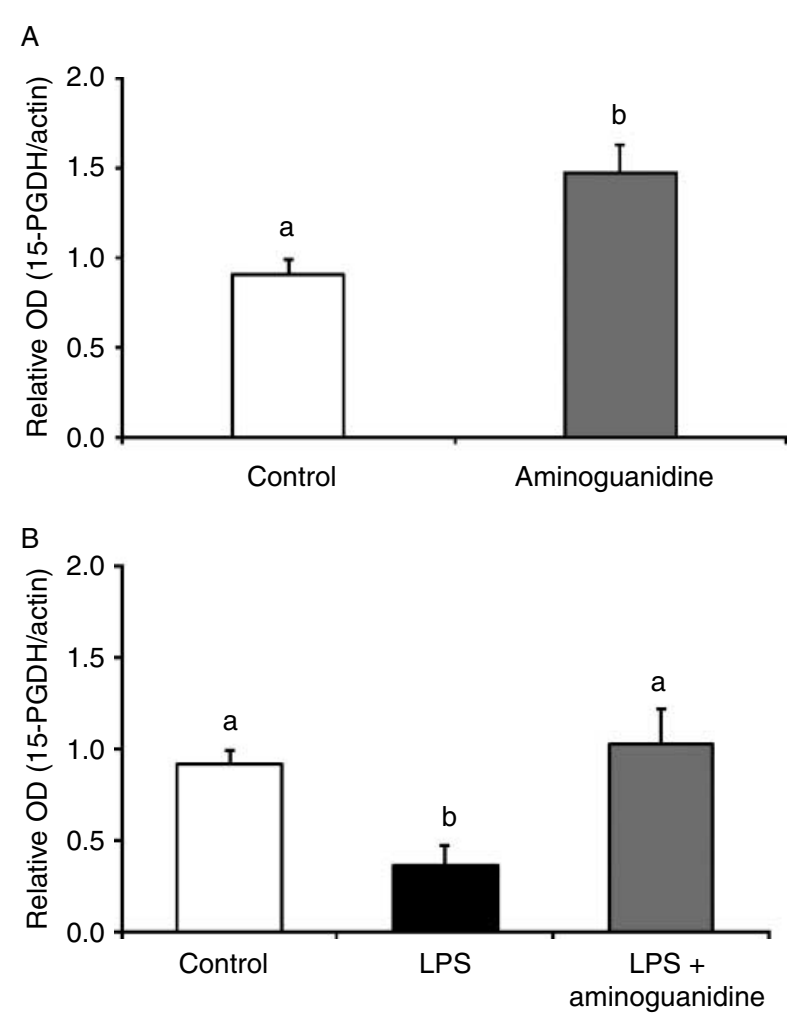

Figure 4 Effect of a nitric oxide synthesis inhibitor (aminoguanidine) on HPGD protein expression. BALB/c mice were injected on days 6 and 7 of gestation (as indicated in Table 1) with vehicle (PBS) or aminoguanidine (6 mg/mouse) (A), LPS, and LPS + aminoguanidine (B) and killed after $6 \mathrm{~h}$ of LPS treatment. HPGD protein expression was determined in uterine tissue by western blot. Normalized data (OD $15-\mathrm{PGDH} / \mathrm{OD}$ actin) are expressed as mean \pm s.E.M., $n=5$ mice per group. Comparisons of means for more than two groups were performed using ANOVA. Pairwise comparisons were made with Tukey's or Student's $t$-test. Dissimilar superscripts denote significantly different values $(P<0.01)$. OD, optical density.

part of the disease process. To evaluate the possible regulatory role of endogenous peroxynitrite on PG catabolism, we investigated the effect of quercetin, a selective peroxynitrite scavenger on uterine $\mathrm{PGE}_{2}$ levels, and HPGD protein expression. Mice were injected with LPS $(1 \mu \mathrm{g} / \mathrm{g})$ and quercetin on day 7 of gestation and were killed $6 \mathrm{~h}$ after treatment. The coadministration did not prevent the increase in $\mathrm{PGE}_{2}$ levels or decrease in HPGD protein expression induced by LPS in uterus (Fig. $6 \mathrm{~A}$ and $\mathrm{B}$ respectively). These results indicate that alterations in the metabolism of uterine $\mathrm{PGE}_{2}$ observed by LPS administration appear to be not associated with the production of this particularly detrimental molecule.

\section{Discussion}

In this study, the regulation of uterine $\mathrm{PGE}_{2}$ catabolism under inflammatory conditions during early pregnancy was examined. As we mentioned earlier, we have previously developed a mouse model to study the mechanisms of LPS-induced pregnancy loss. In BALB/C mice, the treatment with $1 \mu \mathrm{g} / \mathrm{g}$ of body weight (i.p.) of LPS on day 7 of gestation produced complete embryonic resorption at $24 \mathrm{~h}$. We have found that after LPS administration, HPGD protein is expressed predominantly in the uterus, while in the decidua, the expression is almost undetectable. This result agrees with Gao et al. (2007) who detected Hpgd mRNA and protein expression in the mouse uterus during embryo implantation. For this reason, we have focused on studying the modulation of 15-PGDH in the uterus.

We observed that administration of LPS decreased the HPGD protein expression after $6 \mathrm{~h}$ of treatment (Fig. 2). Our result is in agreement with Wang \& Hirsch (2003) who have shown that after treatment with heat-killed Escherichia coli, the expression of Hpgd (mRNA) significantly decreased in the myometrium of TIr4 wild-type pregnant mice but not in T/r4-mutant mice; toll-like receptor 4 (TLR4) is a critical component of the LPS signaling. Endotoxin administration also decreases the 15-PGDH expression in the lung of male $B d f 1$ mice, showing the maximum reduction (mRNA and protein) after $6 \mathrm{~h}$ of treatment with LPS (Hahn et al. 1998). Moreover, Ivanov et al. (2003) showed a decrease in Hpgd expression (mRNA) of liver and lung in a model of systemic inflammation in rats (Ivanov \& Romanovsky 2004). Contrary to what we have found, Menon et al. (2006) have documented an increment in Hpgd mRNA expression after LPS stimulation, but this study was performed with placental membranes in a tissue explant system.

Several evidences, including those provided by our laboratory, have shown that treatment with LPS increases $\mathrm{PGE}_{2}$ levels in the uterus (Herath et al. 2006, Aisemberg et al. 2007). Figure 1 shows that this is due in part to increased uterine activity of the PGE synthase in our

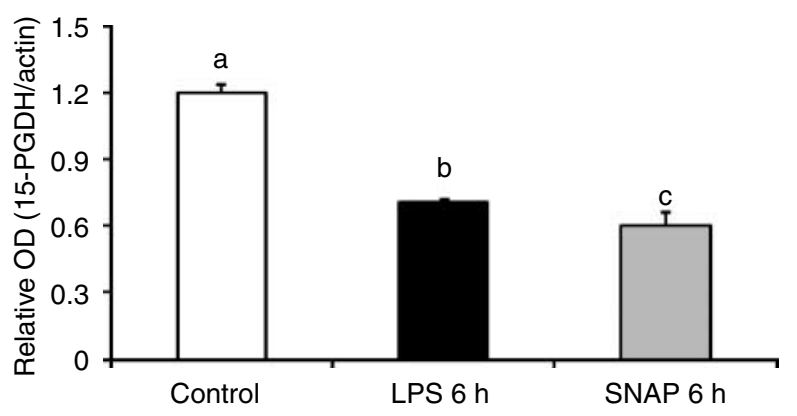

Figure 5 Effect of a nitric oxide donor (SNAP) on HPGD protein expression. BALB/c mice were injected on day 7 of pregnancy with vehicle (PBS), LPS (1 $\mu \mathrm{g} / \mathrm{g})$, or SNAP $(3 \mathrm{mg} / \mathrm{kg})$ and killed after $6 \mathrm{~h}$ of treatment. HPGD protein expression was determined in uterine tissue by western blot. Normalized data (OD 15-PGDH/OD actin) are expressed as mean \pm s.E.M., $n=5$ mice per group. Comparisons of means were performed using ANOVA and Tukey's test. Dissimilar superscripts denote significantly different values $(P<0.001)$. OD, optical density; SNAP, $S$-nitroso- $\mathrm{N}$-acetyl-penicillamine. 

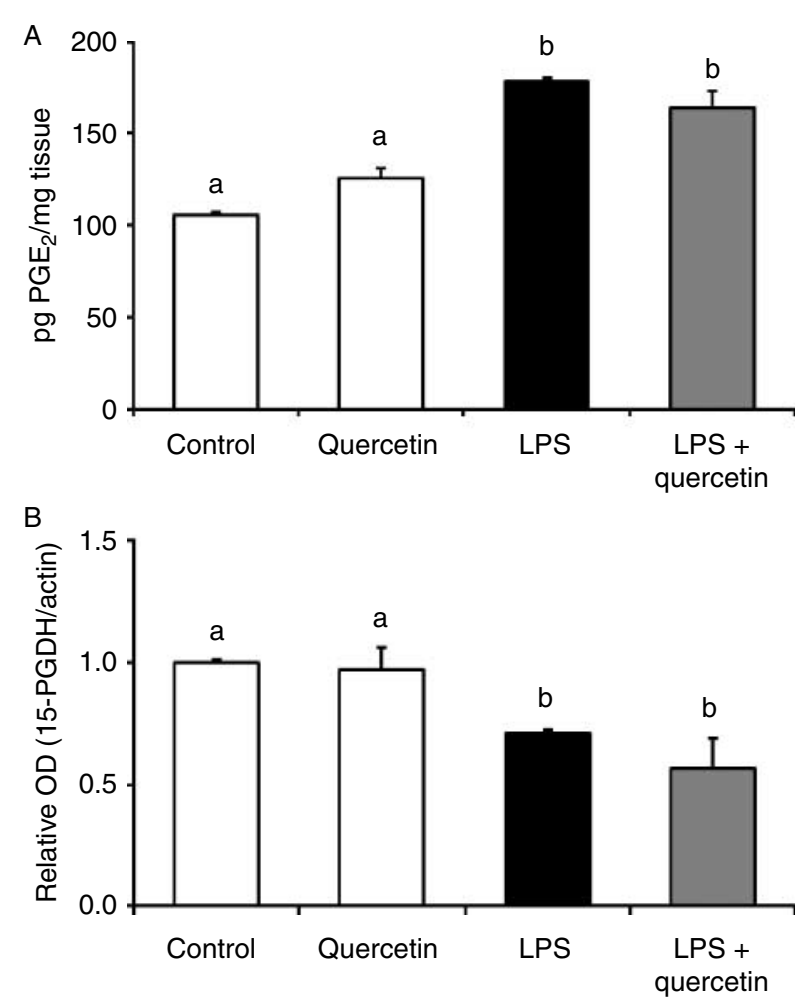

Figure 6 Effect of a peroxynitrite scavenger (quercetin) on $\mathrm{PGE}_{2}$ production and HPGD protein expression. BALB/c mice were injected on day 7 of pregnancy with vehicle, quercetin $(10 \mathrm{mg} / \mathrm{kg})$, LPS, and LPS + quercetin and killed after $6 \mathrm{~h}$ of LPS treatment. (A) PGE $\mathrm{P}_{2}$ levels ( $n=5$ mice per group) and (B) HPGD protein expression ( $n=7$ mice per group) were determined in uterus by RIA and western blot respectively. Mean \pm S.E.M. was expressed as pg $\mathrm{PGE}_{2} / \mathrm{mg}$ tissue $(\mathrm{A})$ and the relative optical density of the 15-PGDH band to that of $\beta$-actin (B).

Comparisons of means were performed using ANOVA and Tukey's test. Dissimilar superscripts denote significantly different values $(P<0.05)$. OD, optical density.

model of pregnancy loss. In parallel was found that LPS treatment reduces levels of PGE metabolites (Fig. 3), which reinforces the reduced enzyme activity that we have previously observed. In accordance with this, Brown et al. (1998) were able to detect a significant decrease in the levels of PG metabolites following incubation with LPS in explants from human fetal membranes. Based on these results, we suggest that in our model, the mechanism by which LPS regulates the levels of $\mathrm{PGE}_{2}$ is by increasing and decreasing PGE synthase activity and HPGD protein expression respectively.

The endometrium is a target tissue for the ovarian steroid hormones estradiol and progesterone. There is now compelling evidence that 15-PGDH (activity and expression) is induced by progesterone (Casey et al. 1980, Kelly et al. 1986, Greenland et al. 2000). In addition, administration of mifepristone, a progesterone receptor antagonist during the luteal phase, induces a decrease in HPGD protein levels in human and monkey endometrium (Nayak et al. 1998, Hapangama et al. 2002). We found that LPS treatment $(1 \mu \mathrm{g} / \mathrm{g}$, i.p., on day 7 of pregnancy) resulted in a significant decrease in serum progesterone levels after 6, 12, and $24 \mathrm{~h}$ of endotoxin administration (Aisemberg J, Vercelli CA, Bariani MV, Billi SC, Wolfson ML \& Franchi AM 2012, submitted manuscript). This allows us to suggest that because LPS induces a decrease in progesterone levels, regulation of 15-PGDH may result from a direct effect of LPS or an indirect effect through progesterone or both.

To our knowledge, this is the first study reporting that 15-PGDH is modulated by nitric oxide in the uterus of pregnant mice. We have shown that nitric oxide contributes to down-modulation of HPGD protein levels under inflammatory conditions. First, we have found that treatment with aminoguanidine (the selective inducible nitric oxide synthase inhibitor) upregulates HPGD protein expression (Fig. 4A). In addition, the reduction in 15-PGDH expression due to LPS treatment leads to HPGD protein levels to control values by the coadministration of the inhibitor (Fig. 4B). These findings were reinforced by the data obtained from experiments in which the animals were injected with the nitric oxide donor, SNAP (Fig. 5).

During an inflammatory setting induced by endotoxins, PGs and nitric oxide are released simultaneously in large quantities (Ogando et al. 2003, Aisemberg et al. 2007). In our model of pregnancy loss, the administration of LPS increases PGs and nitric oxide production in the uterus. In this model, we have also observed that the administration of aminoguanidine, an inducible nitric oxide synthase inhibitor, is able to block the LPSinduced embryonic resorption. In this sense, inhibition of 15-PGDH expression by nitric oxide could partly explain the increase in PG levels. In addition, a model of preterm labor induced by infection was demonstrated that the co-administration of LPS and aminoguanidine prevents preterm birth and inhibits increased PGs and nitric oxide (Cella et al. 2010). Furthermore, no changes were found in the expression of 15-PGDH (Fig. 6B) and $\mathrm{PGE}_{2}$ production (Fig. 6A) in the uterus from animals treated with LPS and quercetin, the scavenger of peroxynitrite. It is worth noting that previous work with this model showed that quercetin does not prevent embryonic resorption process (Aisemberg et al. 2007). These latter results indicate that peroxynitrite is not involved in the resorption process, at least in the modulation mechanism of PG catabolism, in this model of pregnancy loss induced by LPS.

In summary, this study demonstrated that LPS and nitric oxide modulate the expression of $15-\mathrm{PGDH}$ enzyme and that the increase in uterine PGs levels induced by LPS treatment is also a product of their reduced catabolism. These results suggest that 15-PGDH may be a new target for regulating PGs levels in pathological situations of pregnancy such as abortion or premature delivery induced by endotoxins. 


\section{Materials and Methods}

\section{Reagents}

$(5,6,8,11,12,14,15-3 \mathrm{H}(\mathrm{N}))$ - PGE2 (specific activity: 100-200 Ci/mmol) was provided by PerkinElmer Life and Analytical Sciences, Inc. (Walthman, MA, USA). LPS from E. coli 05:B55, aminoguanidine hydrochloride, Quercetin dihydrate, SNAP, anti- $\beta$-actin antibody, glutathione, standard, and antiserum for PGE2 RIA were purchased from Sigma Chemical Co. PGH2 and Prostaglandin E Metabolite EIA kit were purchased from Cayman Chemical Co. (Ann Arbor, MI, USA). TRIzol reagent, Moloney murine leukemia virus reverse transcriptase (M-MLVRT), RNAse-free DNAse, and random primers were purchased from Invitrogen Life Technologies Co. The anti-PGDH antibody was a gift from Dr Tai Hsin-Hsiung (Department of Pharmaceutical Sciences College of Pharmacy University of Kentucky Lexington, USA). HRP-conjugated secondary antibody was from Jackson ImmunoResearch Laboratories, Inc. (West Grove, PA, USA). The western blotting reagents were obtained from Bio-Rad Laboratories. All other chemicals were analytical grade.

\section{Animals and treatments}

Virgin female mice of the BALB/C strain, 8- to 12-week-old and 25-30 g of weight, were paired with adult BALB/C males and the day of appearance of the post-coitum vaginal plug was taken as day 0 of gestation. Animals received food and water ad libitum and were housed under controlled conditions of light $\left(12 \mathrm{~h}\right.$ light $/ 12 \mathrm{~h}$ darkness) and temperature $\left(23-25^{\circ} \mathrm{C}\right)$. Mice were killed by $\mathrm{CO}_{2}$ inhalation. The experimental procedures reported here were approved by the Animal Care Committee of the Center for Pharmacological and Botanical Studies of the National Research Council (CEFYBO-CONICET) and by The Institutional Committed for the Care and Use of Laboratory animals from the School of Medicine, University of Buenos Aires.

On days 6 and 7 of gestation, animals were divided randomly into different groups of treatment for the in vivo experiments. Table 1 shows the different protocols, doses, routes of administration, and vehicles used. We have previously shown (Ogando et al. 2003) that LPS produced a significant increase in nitric oxide production in uterus at 6, 12, and $24 \mathrm{~h}$ after injection reaching a maximum at $6 \mathrm{~h}$. So in the present work, treated mice were killed $6 \mathrm{~h}$ after LPS

Table 1 Protocols, doses, routes of administration, and vehicles used for in vivo treatments.

\begin{tabular}{|c|c|c|c|c|}
\hline Treatment & Dose & Vehicle & $\begin{array}{l}\text { Route of } \\
\text { administration }\end{array}$ & $\begin{array}{l}\text { Day and hour } \\
\text { of injection }\end{array}$ \\
\hline LPS & $1 \mu \mathrm{g} / \mathrm{g}$ & PBS & I.p. & Day $7 / 0900 \mathrm{~h}$ \\
\hline $\begin{array}{l}\text { Amino- } \\
\text { guanidine }\end{array}$ & $6 \mathrm{mg} / \mathrm{mouse}$ & PBS & I.p. & $\begin{array}{l}\text { Day } 6 / 0900 \mathrm{~h} \\
\text { Day } 7 / 0900 \\
\text { and } 1300 \mathrm{~h}\end{array}$ \\
\hline SNAP & 3 mg/kg & PBS & I.p. & Day $7 / 0900 \mathrm{~h}$ \\
\hline Quercetin & $10 \mathrm{mg} / \mathrm{kg}$ & Corn oil & S.c. & Day $7 / 0900 \mathrm{~h}$ \\
\hline
\end{tabular}

In all cases, the animals were killed $6 \mathrm{~h}$ after LPS injection.

${ }^{a}$ Corresponds to the day of gestation in which the animal was injected. administration. In mice, the endometrial estroma undergoes dramatic cytologic changes to form a decidua in response to the implanting embryo. After attachment, the embryo becomes embedded in an enlarging mass of decidual tissue, and this tissue is separated from uterine adventitia by an inner circular and an outer longitudinal smooth muscle layer (myometrium). After isolation of each implantation site, the uterus was cut open along the longitude axis. Decidual tissues were separated from myometrium by gently scrapping off the decidua. The authors use the term 'uterus' for the tissue composed of nondecidualized endometrium, myometrium, and adventitia/ serosa and the term decidua for the decidualizing stromal cells and the embryo. Uterus and decidua from each implantation site were separated and immediately frozen at $-80{ }^{\circ} \mathrm{C}$.

\section{Determination of PGE synthase activity}

Enzyme activity in uterine tissue was measured by assessing the conversion of $\mathrm{PGH}_{2}$ to $\mathrm{PGE}_{2}$ as in Murakami et al. (2000) with minor modifications. Tissues were homogenized in a $0.01 \mathrm{~mol} / \mathrm{l}$ Tris- $\mathrm{HCl}$ buffer $(\mathrm{pH}=8)$ and sonicated. After centrifugation, $100 \mu \mathrm{g}$ total protein were incubated with $2 \mu \mathrm{g} \mathrm{PGH}_{2}$ for $1 \mathrm{~min}$ at $24{ }^{\circ} \mathrm{C}$ in $0.1 \mathrm{ml}$ of $1 \mathrm{~mol} / \mathrm{l}$ Tris- $\mathrm{HCl}(\mathrm{pH}=8)$ containing $0.002 \mathrm{~mol} / \mathrm{l}$ glutathione. After terminating the reaction by the addition of $20 \mu \mathrm{l}$ of $6 \mathrm{M} \mathrm{HCl}$, samples were dried under vacuum and resuspended to determine the levels of $\mathrm{PGE}_{2}$ by RIA. Results were expressed as $n g \mathrm{PGE}_{2} / \mathrm{mg}$ protein per $\mathrm{h}$.

\section{$P G E_{2}$ determination}

$\mathrm{PGE}_{2}$ was quantified by specific RIA. Uteri and deciduas were removed, cleaned, and rinsed in cold PBS. Tissues were weighed and incubated in $2 \mathrm{ml}$ modified Krebs-Ringer bicarbonate solution $(0.118 \mathrm{~mol} / \mathrm{l} \mathrm{NaCl}, 0.005 \mathrm{~mol} / \mathrm{l} \mathrm{KCl}, 0.001 \mathrm{~mol} / \mathrm{l}$ $\mathrm{KH}_{2} \mathrm{PO}_{4}, 0.001 \mathrm{~mol} / \mathrm{l} \mathrm{MgSO}_{4} \times 7 \mathrm{H}_{2} \mathrm{O}, 0.025 \mathrm{~mol} / \mathrm{l} \mathrm{NaHCO}_{3}$, and $0.011 \mathrm{~mol} / \mathrm{l}$ glucose) in $95 \% \mathrm{O}_{2} / 5 \% \mathrm{CO}_{2}$ atmosphere at $37{ }^{\circ} \mathrm{C}$ for $1 \mathrm{~h}$. PGs were acidified to $\mathrm{pH} 3$ with $1 \mathrm{~N} \mathrm{HCl}$ and extracted twice with $2 \mathrm{ml}$ ethyl acetate. Samples were subsequently dried under vacuum. These samples were store at $-20^{\circ} \mathrm{C}$ before analysis for no longer than 3 weeks to minimize degradation of lipids and they were resuspended in RIA buffer $\left(0.007 \mathrm{~mol} / / \mathrm{K}_{2} \mathrm{HPO}_{4} \times 3 \mathrm{H}_{2} \mathrm{O}, 0.003 \mathrm{~mol} / \mathrm{l} \mathrm{K \textrm {K } _ { 2 }} \mathrm{PO}_{4}\right.$, $0.154 \mathrm{~mol} / \mathrm{I} \mathrm{NaCl}, 0.007 \mathrm{~mol} / \mathrm{l}$ albumin bovine, and $0.015 \mathrm{~mol} / \mathrm{l}$ sodium azide, $\mathrm{pH}=7.4$ ) the day of the assay. $\mathrm{PGE}_{2}$ antiserum was highly specific and showed low cross-reactivity, $<0.1 \%$ with other PGs. Intra- and interassay variations were $<8 \%$. Values were expressed as pg $\mathrm{PGE}_{2} / \mathrm{mg}$ tissue.

\section{Quantification of $\mathrm{PGE}_{2}$ metabolites}

Metabolites were determined in uteri and deciduas by PGE Metabolite EIA Kit (cat. no. 514531.1, Cayman Chemical Co.) according to the manufacturer's recommendations. $\mathrm{PGE}_{2}$ is not chemically stable and is rapidly converted to its 13,14-dihydro15-keto metabolite. The $\mathrm{PGE}_{2}$ metabolite assay kit converts all the immediate $\mathrm{PGE}_{2}$ metabolites to a single stable derivative that could be easily quantified by EIA. Metabolite levels are reported as pg $\mathrm{PGE}_{2}-\mathrm{M} / \mathrm{mg}$ tissue. 


\section{Western blot analysis}

Isolated tissues were homogenized (Ultra Turrax, T25 basic, IKA Labortechnik, Staufen, Germany) in RIPA buffer $(0.05 \mathrm{~mol} / \mathrm{l}$ Tris- $\mathrm{HCl} \mathrm{pH}=7.4$, Triton X-100 1\% (v/v), $0.15 \mathrm{~mol} / \mathrm{l} \mathrm{NaCl}$, $0.001 \mathrm{~mol} / \mathrm{I}$ EDTA, and $0.25 \% \mathrm{w} / \mathrm{v}$ sodium deoxycholate) with freshly added protease inhibitor cocktail $(10 \mu \mathrm{g} / \mathrm{ml}$ leupeptin, $2 \mu \mathrm{g} / \mathrm{ml}$ aprotinin, $100 \mu \mathrm{g} / \mathrm{ml}$ soybean trypsin inhibitor, $1 \mathrm{mmol} / \mathrm{l}$ EDTA, $1 \mathrm{mg} / \mathrm{ml}$ benzamidine, $10 \mu \mathrm{g} / \mathrm{ml}$ dithiothreitol, and $1 \mathrm{mg} / \mathrm{ml}$ caproid acid). Tissues were sonicated (Ultrasonic Cell Disrupter, Microson, Heat systems, Inc., New York NY, USA) for $30 \mathrm{~s}$, centrifuged at $1500 \mathrm{~g}$ for $5 \mathrm{~min}$, and protein concentration was determined by the Bradford assay (Bradford 1976). Proteins (100 $\mu \mathrm{g} /$ lane) were separated by electrophoresis in $12 \%$ SDS-PAGE gel and transferred to a nitrocellulose membrane. Membranes were blocked using 5\% (w/v) dried nonfat milk and then incubated overnight at $4{ }^{\circ} \mathrm{C}$ with the primary antibody, an antisera against mouse 15-PGDH (1:500 containing 3\% of dried nonfat milk, diluted in PBS). After washing with $0.1 \%(\mathrm{v} / \mathrm{v})$ PBS-Tween 20, membranes were incubated for 15 min with the $\beta$-actin antibody (1:4000, diluted in PBS). After that, they were washed followed by $1 \mathrm{~h}$ incubation with HRP-conjugated antirabbit secondary antibody (1:20 000 containing 2\% of milk, diluted in PBS) and developed using the ECL system. The corresponding immunoreactive bands were registered with a digital camera Olympus C-5060 and analyzed using the software package Image J (NIH, Bethesda, MD, USA; http://imagej.nih.gov/ij/). Results were expressed as the ratio of the optical density of the $15-\mathrm{PGDH}$ band normalized with the optical density of $\beta$-actin.

\section{Statistical analysis}

Data were analyzed using GraphPad Prism version 3.0 (GraphPad Software, Inc., San Diego, CA, USA). Pairwise comparisons of means were made with Student's $t$-test or Tukey's multiple comparison tests for unequal replicates. Comparisons between means for more than two groups were performed using one-way ANOVA. All values presented in this study represent mean \pm s.E.M. of at least three independent determinations. Differences were considered significant when $P$ was 0.05 or less. On graphs, dissimilar superscripts (letters) denote significantly different values.

\section{Declaration of interest}

The authors declare that there is no conflict of interest that could be perceived as prejudicing the impartiality of the research reported.

\section{Funding}

This work was supported by ANPCyT (PICT 2006/no. 2165) and by the National Research Council - CONICET (PIP 2008/no. 2204).

\section{Acknowledgements}

The authors would like to thank Mrs Ramona Morales and Mrs Patricia Fernández for their excellent technical support. The authors gratefully acknowledge Dr Tai Hsin-Hsiung for kindly providing the anti-15-PGDH antibody.

\section{References}

Aisemberg J, Vercelli CA, Billi S, Ribeiro ML, Ogando D, Meiss R, McCann SM, Rettori V \& Franchi AM 2007 Nitric oxide mediates prostaglandins' deleterious effect on lipopolysaccharide-triggered murine fetal resorption. PNAS 104 7534-7539. (doi:10.1073/pnas. 0702279104)

Bradford M 1976 A rapid and sensitive method for the quantitation of microgram quantities of protein utilizing the principle of protein-dye binding. Analytical Biochemistry 72 248-254. (doi:10.1016/00032697(76)90527-3)

Brown NL, Alvi SA, Elder MG, Bennett PR \& Sullivan MH 1998 Interleukin$1 \beta$ and bacterial endotoxin change the metabolism of prostaglandins E2 and F2 $\alpha$ in intact term fetal membranes. Placenta 19 625-630. (doi:10.1016/S0143-4004(98)90024-8)

Casey ML, Hemsell DL, Johnston JM \& MacDonald PC 1980 NAD +-dependent 15-hydroxyprostaglandin dehydrogenase activity in human endometrium. Prostaglandins 19 115-122. (doi:10.1016/00906980(80)90159-8)

Cella M, Farina MG, Dominguez Rubio AP, Di Girolamo G, Ribeiro ML \& Franchi AM 2010 Dual effect of nitric oxide on uterine prostaglandin synthesis in a murine model of preterm labour. British Journal of Pharmacology 161 844-855. (doi:10.1111/j.1476-5381.2010.00911.x)

Gao F, Lei W, Diao HL, Hu SJ, Luan LM \& Yang ZM 2007 Differential expression and regulation of prostaglandin transporter and metabolic enzymes in mouse uterus during blastocyst implantation. Fertility and Sterility 88 (4 Suppl) 1256-1265. (doi:10.1016/j.fertnstert.2007.02.054)

Greenland KJ, Jantke I, Jenatschke S, Bracken KE, Vinson C \& Gellersen B 2000 The human NAD +-dependent 15-hydroxyprostaglandin dehydrogenase gene promoter is controlled by Ets and activating protein-1 transcription factors and progesterone. Endocrinology 141 581-597. (doi:10.1210/en.141.2.581)

Hahn EL, Clancy KD, Tai HH, Ricken JD, He LK \& Gamelli RL 1998 Prostaglandin E2 alterations during sepsis are partially mediated by endotoxin-induced inhibition of prostaglandin 15-hydroxydehydrogenase. Journal of Trauma 44 777-781. (doi:10.1097/00005373-19980 5000-00006)

Hapangama DK, Critchley HOD, Henderson TA \& Baird DT 2002 Mifepristone-induced vaginal bleeding is associated with increased immunostaining for cyclooxygenase-2 and decrease in prostaglandin dehydrogenase in luteal phase endometrium. Journal of Clinical Endocrinology and Metabolism 87 5229-5234. (doi:10.1210/jc.2002020429)

Herath S, Fischer DP, Werling D, Williams EJ, Lilly ST, Dobson H, Bryant CE \& Sheldon IM 2006 Expression and function of toll-like receptor 4 in the endometrial cells of the uterus. Endocrinology 147 562-570. (doi:10. 1210/en.2005-1113)

Ivanov AI \& Romanovsky AA 2004 Prostaglandin E2 as a mediator of fever: synthesis and catabolism. Frontiers in Bioscience: a Journal and Virtual Library 9 1977-1993. (doi:10.2741/1383)

Ivanov Al, Scheck AC \& Romanovsky AA 2003 Expression of genes controlling transport and catabolism of prostaglandin E2 in lipopolysaccharide fever. American Journal of Physiology 284 R698-R706.

Kankofer M 1999 The enzymes responsible for the metabolism of prostaglandins in bovine placenta. Prostaglandins, Leukotrienes, and Essential Fatty Acids 61 359-362. (doi:10.1054/plef.1999.0109)

Keirse MJ, Erwich JJ \& Klok G 1985 Increase in placental 15-hydroxyprostaglandin dehydrogenase in the first half of human pregnancy. Prostaglandins 30 131-140. (doi:10.1016/S0090-6980(85)80017-4)

Kelly RW, Healy DL, Cameron MJ, Cameron IT \& Baird DT 1986 The stimulation of prostaglandin production by two antiprogesterone steroids in human endometrial cells. Journal of Clinical Endocrinology and Metabolism 62 1116-1123. (doi:10.1210/jcem-62-6-1116)

Lamont RF \& Sawant SR 2005 Infection in the prediction and antibiotics in the prevention of spontaneous preterm labour and preterm birth. Minerva Ginecologica 57 423-433.

Menon R, Merialdi M, Lombardi SJ \& Fortunato SF 2006 Differences in the placental membrane cytokine response: a possible explanation for the racial disparity in preterm birth. American Journal of Reproductive Immunology 56 112-118. (doi:10.1111/j.1600-0897.2006.00394.x)

Murakami M, Naraba H, Tanioka T, Semmyo N, Nakatani Y, Kojima F, Ikeda T, Fueki M, Ueno A, Oh S et al. 2000 Regulation of prostaglandin 
E2 biosynthesis by inducible membrane-associated prostaglandin E2 synthase that acts in concert with cyclooxygenase-2. Journal of Biological Chemistry 275 32783-32792. (doi:10.1074/jbc. M003505200)

Nayak NR, Sengupta J \& Ghosh D 1998 Antinidatory effect of luteal phase administration of mifepristone (RU486) is associated with changes in endometrial prostaglandins during the implantation window. Contraception 58 111-117. (doi:10.1016/S0010-7824(98)00068-7)

Ogando DG, Paz D, Cella M \& Franchi AM 2003 The fundamental role of increased production of nitric oxide in lipopolysaccharide-induced embryonic resorption in mice. Reproduction 125 95-110. (doi:10.1530/ rep.0.1250095)

Penta M, Lukic A, Conte MP, Chiarini F, Fioriti D, Longhi C, Pietropaolo V, Vetrano G, Villaccio B, Degener AM et al. 2003 Infectious agents in tissues from spontaneous abortions in the first trimester of pregnancy. New Microbiologica 26 329-337.

Romero R, Mazor M, Wu YK, Sirtori M, Oyarzun E, Mitchell MD \& Hobbins JC 1988 Infection in the pathogenesis of preterm labor. Seminars in Perinatology 12 262-279.

Rouzer CA \& Marnett LJ 2009 Cyclooxygenases: structural and functional insights. Journal of Lipid Research 50 (Suppl) S29-S34. (doi:10.1194/jlr. R800042-JLR200)
Sangha RK, Walton JC, Ensor CM, Tai HH \& Challis JR 1994 Immunohistochemical localization, messenger ribonucleic acid abundance, and activity of 15-hydroxyprostaglandin dehydrogenase in placenta and fetal membranes during term and preterm labor. Journal of Clinical Endocrinology and Metabolism 78 982-989. (doi:10.1210/jc.78.4.982)

Szabó C, Ischiropoulos H \& Radi R 2007 Peroxynitrite: biochemistry, pathophysiology and development of therapeutics. Nature Reviews. Drug Discovery 6 662-680. (doi:10.1038/nrd2222)

Tai HH, Cho H, Tong M \& Ding Y 2006 NAD+-linked 15-hydroxyprostaglandin dehydrogenase: structure and biological functions. Current Pharmaceutical Design 12 955-962. (doi:10.2174/13816120 6776055958)

Wang H \& Hirsch E 2003 Bacterially-induced preterm labor and regulation of prostaglandin-metabolizing enzyme expression in mice: the role of toll-like receptor 4. Biology of Reproduction 69 1957-1963. (doi:10.1095/biolreprod.103.019620)

Received 21 May 2012

First decision 29 June 2012

Accepted 26 July 2012 